\title{
Effect of growth regulators on 'Brookfield' apple gas diffusion and metabolism under controlled atmosphere storage
}

\author{
Auri Brackmann ${ }^{(1)}$, Fabio Rodrigo Thewes ${ }^{(1)}$, Rogerio de Oliveira Anese ${ }^{(1)}$ and Vanderlei Both ${ }^{(1)}$
}

(1)Universidade Federal de Santa Maria, Departamento de Fitotecnia, Avenida Roraima, n 1.000, Bairro Camobi, CEP 97105-900 Santa Maria, RS, Brazil. E-mail: auribrackmann@gmail.com, fthewes@yahoo.com.br, rogerio_anese@yahoo.com.br, vanderleiboth@yahoo.com.br

\begin{abstract}
The objective of this work was to evaluate the effect of growth regulators on gas diffusion and on metabolism of 'Brookfield' apple, and to determine their correlation with quality characteristics of fruit stored in controlled atmosphere. A completely randomized design was used with four replicates. After eight months of storage, the effects of water (control), aminoethoxyvinylglycine (AVG), AVG + ethephon, AVG + naphthaleneacetic acid (NAA), ethephon + NAA, sole NAA, 1-MCP, ethylene absorption by potassium permanganate (ABS), AVG + ABS, and of AVG + 1-MCP - applied at different rates and periods - were evaluated on: gas diffusion rate, ethylene production, respiratory rate, internal ethylene concentration, internal $\mathrm{CO}_{2}$ content, mealiness, and intercellular space. Fruit from the control and sole NAA treatments had the highest mealiness occurrence. Growth regulators significantly changed the gaseous diffusion through the pulp of 'Brookfield' apple, mainly in the treatment AVG + ABS, which kept the highest gas diffusion rate. NAA spraying in the field, with or without another growth regulator, increased ripening metabolism by rising ethylene production and respiration rate, and reduced gas diffusion during shelf life. AVG spraying cannot avoid the ethephon effect during the ripening process, and reduces both the internal space and mealiness incidence, but it is not able to induce ethylene production or to increase respiration rates.
\end{abstract}

Index terms: Malus domestica, aminoethoxyvinylglycine, ethylene absorption, fruit quality, 1-methylcyclopropene.

\section{Efeito de reguladores de crescimento na difusão de gases e no metabolismo de maçãs 'Brookfield' em armazenamento em atmosfera controlada}

\begin{abstract}
Resumo - O objetivo deste trabalho foi avaliar o efeito de reguladores de crescimento na difusão de gases e no metabolismo de maçãs 'Brookfield', e determinar sua correlação com características dos frutos armazenados em atmosfera controlada. Utilizou-se o delineamento experimental inteiramente casualizado com quatro repetições. Após oito meses de armazenamento, os efeitos de água (controle), aminoetoxivinilglicina (AVG), AVG + ethephon, AVG + ácido naftalenoacético (ANA), ethephon + ANA, somente ANA, 1-MCP, absorção de etileno por permanganato de potássio (ABS), AVG + ABS, e de AVG + 1-MCP - aplicados em diferentes doses e épocas - foram avaliados sobre: taxa de difusão de gases, produção de etileno, taxa respiratória, concentração interna de etileno, concentração interna de $\mathrm{CO}_{2}$, polpa farinácea e espaço interno. Frutos dos tratamentos controle e ANA sozinha apresentaram a maior ocorrência de polpa farinácea. Os reguladores de crescimento modificaram significativamente a difusão gasosa pela polpa de maçãs 'Brookfield', principalmente no tratamento $\mathrm{AVG}+\mathrm{ABS}$, que manteve a maior taxa de difusão de gases. A aplicação de ANA no campo, com ou sem outro regulador de crescimento, acelerou o metabolismo de amadurecimento, pelo aumento na produção de etileno e na taxa respiratória, e reduziu a difusão de gases durante a vida de prateleira. Aplicação de AVG não evita o efeito do ethephon durante o amadurecimento, reduz o espaço interno e a ocorrência de polpa farinácea, mas não é capaz de induzir a produção de etileno ou de aumentar a taxa respiratória.
\end{abstract}

Termos para indexação: Malus domestica, aminoetoxivinilglicina, absorção de etileno, qualidade de frutos, 1-metilciclopropeno.

\section{Introduction}

After harvest, fruit continue the respiration pathways in which both $\mathrm{O}_{2}$ consumption and $\mathrm{CO}_{2}$ production occur. Considering that $\mathrm{O}_{2}$ and $\mathrm{CO}_{2}$ should permeate skin and fruit tissue for the respiration process to properly occur, gas diffusion plays a fundamental role on fruit quality during postharvest (Argenta et al., 2002).

The consumption of $\mathrm{O}_{2}$ and the production of $\mathrm{CO}_{2}$ cause a gradient in $\mathrm{O}_{2}$ concentration from the epidermis to the fruit cortex (Ho et al., 2006). Gas 
diffusion through apple pulp is essential to avoid an excessive decrease on $\mathrm{O}_{2}$ levels or an increase on internal $\mathrm{CO}_{2}$, which can interfere with the maintenance of postharvest quality.

Gas exchange guarantees the efficacy of controlled atmosphere storage and extends storage life. If, for any reason, gas exchange is hindered, the internal atmosphere changes, which can result in some physiological disorders (flesh browning and mealiness) and in a decrease of fruit quality after storage (Franck et al., 2007). Gas diffusion on apple varies according to the cultivars, harvest dates, and storage time (Schotsmans et al., 2004). Some growth regulators in use in Brazilian apple production can affect the gas diffusion, due to alterations on normal growth of fruit, on its development, and on the gas exchange, which lead to physiological disorders.

Aminoethoxyvinylglycine (AVG) is a growth regulator commonly used in apple production. It delays fruit harvest due to a reduction of ethylene production, which in elevated concentrations can cause fruit drop (Yildiz et al., 2012). Nonetheless, researchers suggest that its preharvest application changes postharvest fruit behaviour because it keeps fruit green color, acidity, and reduces volatile compounds (Steffens et al., 2006; Salas et al., 2011). Ethephon is another growth regulator much used in apples production. It increases the anthocyanin content and changes fruit color of blueberry (Ban et al., 2007) and apple (Steffens et al., 2006). In some orchards, auxins are applied along with ethephon to avoid fruit drop. During postharvest, other products are also used to delay fruit ripening, such as 1-methylcyclopropene (1-MCP) (Fawbush et al., 2008, 2009) and ethylene absorption sachets (ABS) (Brackmann et al., 2010; Corrêa et al., 2011). However, there is little information on the effect of these products on gas diffusion and on ethylene production, respiration rate, and physiological disorders of fruit after storage.

The objective of this work was to evaluate the effect of growth regulators on gas diffusion, and to determine their correlation with quality characteristics of 'Brookfield' apple stored in controlled atmosphere.

\section{Materials and Methods}

The experiment was carried out with two parts, one of them in a field, at a commercial orchard in Vacaria, Rio Grande do Sul, Brazil, and another one at the Postharvest Research Center of the Universidade Federal de Santa Maria. The evaluated treatments were: sprayed water (control); aminoethoxyvinylglycine (AVG) $\left(0.83 \mathrm{~kg} \mathrm{ha}^{-1}\right.$ of Retain at $15 \%$ a.i.), sprayed 30 days before harvest $(\mathrm{BH})$; AVG + ethephon (2.0 $\mathrm{L} \mathrm{ha}^{-1}$ of ethrel at $24 \%$ a.i.), applied ten days $\mathrm{BH} ; \mathrm{AVG}+$ naphthaleneacetic acid (NAA) (40 $\mathrm{g}^{\text {ha }}{ }^{-1} \mathrm{NAA}$ ), sprayed seven days BH; sole NAA, sprayed seven days BH; ethephon + NAA, sprayed seven and ten days $\mathrm{BH}$, respectively; 1-MCP $\left(0.625 \mu \mathrm{L} \mathrm{L}^{-1}\right.$ of Smartfresh at $0.14 \%$ a.i.), applied during postharvest, according to Brackmann et al. (2010); ethylene absorption sachets (ABS), applied during storage using potassium permanganate sachets into the storage chamber; $\mathrm{AVG}+\mathrm{ABS} ; \mathrm{AVG}+1-\mathrm{MCP}$, application one day after harvest. In all assayed treatments in the field, it was used an application volume of $1,000 \mathrm{~L} \mathrm{ha}^{-1}$. Fort each treatment, four replicates and four plants per replicate were used, from which fruit were randomly harvested. At the Postharvest Research Center, fruit were standardized by discarding damaged ones. After standardization, samples were formed with 25 fruit each, which were placed in a hermetically closed chamber under controlled atmosphere conditions, with $1.2 \mathrm{kPa} \mathrm{O}_{2}+2.0 \mathrm{kPa} \mathrm{CO}$ at $1.5 \pm 0.1^{\circ} \mathrm{C}$, at $94 \pm 1.0 \%$ relative humidity, and stored by eight months.

After the storage period, gas diffusion rate was evaluated according to Schotsmans et al. (2003), with modifications - samples 5-mm thick taken from ten fruit per replicate; and ethylene production was determined by packing approximately $1.5 \mathrm{~kg}$ fruit in a $5 \mathrm{~L}$ container hermetically sealed, for approximately one hour, after which two atmosphere aliquots of each container were sampled and introduced into a Varian gas chromatograph Star CX 3400 (Varian, Palo Alto, CA, USA), equipped with a flame-ionization detector (FID) and a Porapak N80/100 column. Temperatures of the column, the injector, and the detector were 90, 140 and $200^{\circ} \mathrm{C}$ respectively. Respiratory rate was determined using atmosphere aliquots from the same container used for ethylene analysis, using a Dani gas chromatograph, model Master GC (Dani Intruments Spa., Viale Brianza, Cologno Monzese, Italy), equiped with a capillary column Carboxen 1006 Plot, for the determination of $\mathrm{CO}_{2}$ concentration ( $\mathrm{mL} \mathrm{CO}_{2} \mathrm{~kg}^{-1}$ per hour). Internal ethylene concentration (IEC) was measured with a vacuum pump, which withdrew internal air from fruit with a $565 \mathrm{~mm} \mathrm{Hg}$ suction pressure. The vacuum pump removed air from 
a container filled with water, in which a sample of ten fruit was immersed. An inverted funnel, with a septum in its thinner end covering the fruit, allowed the air removed from them to be accumulated. Air samples $(1 \mathrm{~mL})$ were injected in the same chromatograph used for ethylene analysis, and the results were expressed in $\mu \mathrm{L} \mathrm{C}_{2} \mathrm{H}_{4} \mathrm{~L}^{-1}$. Internal $\mathrm{CO}_{2}$ content $\left(\mathrm{ICO}_{2}\right)$ was measured from two samples of the same air extracted from fruit, which were injected into the same Dani gas chromatograph used for respiration analysis, in order to obtain $\mathrm{ICO}_{2}$ concentration (in $\mathrm{mL} \mathrm{CO}$ per $100 \mathrm{~mL}$ ). Mealiness (\%) was determined by counting fruit that showed any symptom of mealy flesh. Intercellular space was determined in approximately $50 \mathrm{~g}$ of fruit flesh (from the equatorial region of ten apples) immersed in water and subjected to vacuum $(565 \mathrm{~mm} \mathrm{Hg})$, during $2 \mathrm{~min}$, to infiltrate water in the intercellular space. The intercellular space was obtained by determining the weight difference of the samples, before and after water infiltration, and the results were expressed in $\mathrm{g}$ per $100 \mathrm{~g}$ of pulp.

Both parts of the experiment (field and postharvest work) were conducted in a completly randomized design. Data were subjected to analyses of variance, and the means were compared by the Scott-Knott test, at $5 \%$ probability. The parameters, in percentage, were transformed by the formula $\operatorname{arc} \sin ((\mathrm{x}+0,5) / 100)^{1 / 2}$, before analysis of variance.

\section{Results and Discussion}

Right after cooling rooms were opened, and after the $6^{\text {th }}$ day at room temperature $\left( \pm 20^{\circ} \mathrm{C}\right)$, gas diffusion was higher in fruit which received preharvest AVG application + ethylene absorption (ABS) (Table 1). Fruit subjected to AVG + ABS possibly had higher cell integrity and stability, which resulted in higher gas diffusion (Schotsmans et al., 2004). It is noteworthy that fruit which had high gas diffusion showed higher internal space, and these two parameters had a positive Pearson correlation.

Low gas diffusion was observed on fruit which received NAA sprayed, with $0.488 \mathrm{~mL} \mathrm{CO}_{2} \mathrm{~m}^{-2} \mathrm{~s}^{-1}$, when cooling rooms were opened. When fruit were exposed to room temperature $\left( \pm 20^{\circ} \mathrm{C}\right)$ for six days, a reduction of gas diffusion to $0.416 \mathrm{~mL} \mathrm{CO}_{2} \mathrm{~m}^{-2} \mathrm{~s}^{-1}$ was observed. This reduction suggests an advanced ripening stage of fruit and, accordingly, lower cell integrity. The advanced ripening stage is confirmed by the high internal ethylene concentration, ethylene production, respiration rate and, also, by higher mealiness incidence.

Gas diffusion increased after six days from chamber opening when fruit were treated with AVG, 1-MCP, and ABS, as opposed to what was observed for fruit treated with NAA, NAA + ethephon, or AVG + NAA, in which gas diffusion decreased after six days of shelf life (Table 1).

Table 1. Gas diffusion rate and ethylene production by 'Brookfield' apples, after eight-months storage in controlled atmosphere $\left(1.0 \mathrm{kPa} \mathrm{O}_{2}+2.0 \mathrm{kPa} \mathrm{CO}_{2}\right)$, and after six days of shelf life, at $20^{\circ} \mathrm{C}^{(1)}$.

\begin{tabular}{|c|c|c|c|c|c|c|}
\hline \multirow[t]{2}{*}{ Treatment $^{(2)}$} & \multicolumn{2}{|c|}{ Gas diffusion rate $\left(\mathrm{mL} \mathrm{CO}_{2} \mathrm{~m}^{-2} \mathrm{~s}^{-1}\right)$} & \multirow[t]{2}{*}{ Mean } & \multicolumn{2}{|c|}{ Ethylene production ( $\mu \mathrm{L} \mathrm{C}_{2} \mathrm{H}_{4} \mathrm{~kg}^{-1}$ per hour) } & \multirow[t]{2}{*}{ Mean } \\
\hline & Chamber opening & Six-day-shelf life & & Chamber opening & Six-day-shelf life & \\
\hline Control & $0.566 \mathrm{Ab}$ & $0.532 \mathrm{Ac}$ & 0.549 & $4.27 \mathrm{Ba}$ & $24.76 \mathrm{Aa}$ & 14.51 \\
\hline AVG & $0.532 \mathrm{Bc}$ & $0.608 \mathrm{Ab}$ & 0.577 & $1.11 \mathrm{Bb}$ & $7.02 \mathrm{Ad}$ & 4.06 \\
\hline AVG + ethephon & $0.468 \mathrm{Ad}$ & $0.481 \mathrm{Ac}$ & 0.474 & $1.38 \mathrm{Bb}$ & $8.72 \mathrm{Ad}$ & 5.05 \\
\hline $\mathrm{AVG}+\mathrm{NAA}$ & $0.609 \mathrm{Ab}$ & $0.510 \mathrm{Bc}$ & 0.559 & $0.74 \mathrm{Bb}$ & $9.29 \mathrm{Ad}$ & 5.01 \\
\hline NAA & $0.488 \mathrm{Ad}$ & $0.416 \mathrm{Bd}$ & 0.452 & $3.89 \mathrm{Ba}$ & $14.56 \mathrm{Ac}$ & 9.22 \\
\hline $\mathrm{NAA}+$ ethephon & $0.585 \mathrm{Ab}$ & $0.485 \mathrm{Bc}$ & 0.535 & $3.75 \mathrm{Ba}$ & $20.35 \mathrm{Ab}$ & 12.05 \\
\hline 1-MCP & $0.553 \mathrm{Bb}$ & $0.631 \mathrm{Ab}$ & 0.592 & $0.17 \mathrm{Ab}$ & 1.17Ae & 0.67 \\
\hline ABS & $0.443 \mathrm{Bd}$ & $0.549 \mathrm{Ac}$ & 0.496 & $0.30 \mathrm{Ab}$ & $1.04 \mathrm{Ae}$ & 0.67 \\
\hline $\mathrm{AVG}+\mathrm{ABS}$ & $0.699 \mathrm{Aa}$ & $0.681 \mathrm{Aa}$ & 0.690 & $0.14 \mathrm{Ab}$ & $0.75 \mathrm{Ae}$ & 0.44 \\
\hline $\mathrm{AVG}+1-\mathrm{MCP}$ & $0.622 \mathrm{Ab}$ & $0.603 \mathrm{Ab}$ & 0.612 & $0.34 \mathrm{Ab}$ & $0.61 \mathrm{Ae}$ & 0.47 \\
\hline Mean & 0.556 & 0.549 & - & 1.61 & 8.83 & - \\
\hline $\mathrm{CV}(\%)$ & \multicolumn{2}{|c|}{8.00} & - & \multicolumn{2}{|c|}{28.23} & - \\
\hline
\end{tabular}

${ }^{(1)}$ Means followed by equal letters, lowercase in the columns and uppercase in the lines, do not differ by the Scott-Knott test, at $5 \%$ probability. ${ }^{(2)}$ Control, sprayed water; AVG, aminoethoxyvinylglycine sprayed 30 days before harvest $(\mathrm{BH}) ; \mathrm{AVG}+$ ethephon applied ten days BH; AVG + naphthaleneacetic acid (NAA) sprayed seven days BH; sole NAA, sprayed seven days BH; NAA + ethephon sprayed seven and ten days BH, respectively; 1-MCP applied during postharvest; ABS, ethylene absorption sachets applied during storage. 
Preharvest-NAA sprays can increase ethylene production, and softening fruit cortex is associated with an increased expression of genes involved in ethylene biosynthesis (MdACS1 and MdACO1) or perception (MdERS1), and in cell wall degradation (MdPG1) (Li $\&$ Yuan, 2008). These events are explained by low-cell wall integrity due to a lower-membrane permeability to gas diffusion. This low gas diffusion, combined with an elevated respiration rate (Table 2), culminated in changes in the internal atmosphere. These changes may result in physiological disorders (such as browning and mealiness) because of the anaerobic metabolism (Franck et al., 2007).

One of the main ways to reduce postharvest losses and extend fruit time storage is to acting on ethylene production and action (Steffens et al., 2006; Watkins, 2006; Salas et al., 2011). In the present study, ethylene production was significantly affected by the growth regulators (Table 1). As cooling rooms were opened, a higher ethylene production was found in the control, $\mathrm{NAA}$, and NAA + ethephon treatments. This higher ethylene production is possibly related to the high IEC in fruit of the same treatments (Table 2), as both variables showed a positive correlation. Based on the increase of the mealiness incidence, it is possible to point out that these growth regulators, instead of delaying fruit ripening, seem to advance this process. It is also notable that ethephon application after AVG did not increase ethylene production, which corroborates the observations by Wang \& Dilley (2001) and Steffens et al. (2006) with 'Gala' and 'Jonagold' apples. Ethylene production either increased or remained at a similar value from the opening of cooling rooms up to six days of shelf life.

The respiration rate reflects fruit metabolism and, consequently, its ripening stage (Steffens et al., 2007; Sen et al., 2012). It varies according to the cultivar, storage temperature, mass loss, and atmosphere type in which fruit are stored (Brackmann et al., 2007; Steffens et al., 2007; Pinto et al., 2012). In the present study, however, the respiration rate was also influenced by the growth regulators and the days of shelf life (Table 2). Right after cooling rooms were opened, control and NAA treatments showed the highest respiration rate. The high respiration rate of these fruit has possibly led to higher mealiness incidence (Table 3), considering that these two parameters had a positive correlation (Table 4). However, according to the correlation analysis, the high respiration rate may be related to the ethylene production. This fact has been pointed out by previous researchers (Brackmann et al., 2010; Pinto et al., 2012; Sen et al., 2012). Fruit showed a higher respiration rate in control treatment than in the other ones, after six days of shelf life.

A higher IEC was verified in fruit subjected to NAA and to NAA + ethephon treatments, at the opening

Table 2. Respiration rate and internal ethylene concentration of 'Brookfield' apples after eight-month storage in controlled atmosphere $\left(1.0 \mathrm{kPa} \mathrm{O}_{2}+2.0 \mathrm{kPa} \mathrm{CO}_{2}\right)$ and after six day of shelf life, at $20^{\circ} \mathrm{C}^{(1)}$.

\begin{tabular}{|c|c|c|c|c|c|c|}
\hline \multirow[t]{2}{*}{ Treatment $^{(2)}$} & \multicolumn{2}{|c|}{ Respiration rate $\left(\mathrm{mL} \mathrm{CO}_{2} \mathrm{~kg}^{-1}\right.$ per hour) } & \multirow[t]{2}{*}{ Mean } & \multicolumn{2}{|c|}{ Internal ethylene concentration $\left(\mu \mathrm{L} \mathrm{L}^{-1}\right)$} & \multirow[t]{2}{*}{ Mean } \\
\hline & Chamber opening & Six-day-shelf life & & Chamber opening & Six-day-shelf life & \\
\hline Control & $7.34 \mathrm{Ba}$ & 8.99Aa & 8.16 & $4.48 \mathrm{Ab}$ & $1.26 \mathrm{Bc}$ & 2.87 \\
\hline AVG & $5.88 \mathrm{Ab}$ & $5.80 \mathrm{Ac}$ & 5.84 & $1.38 \mathrm{Ac}$ & $2.39 \mathrm{Ac}$ & 1.88 \\
\hline AVG + ethephon & $6.49 \mathrm{Ab}$ & $5.78 \mathrm{Ac}$ & 6.13 & $2.51 \mathrm{Ac}$ & $1.35 \mathrm{Ac}$ & 1.93 \\
\hline $\mathrm{AVG}+\mathrm{NAA}$ & $5.83 \mathrm{Ab}$ & $5.51 \mathrm{Ac}$ & 5.67 & $2.13 \mathrm{Ac}$ & $3.58 \mathrm{Ab}$ & 2.85 \\
\hline NAA & 7.48Aa & $6.75 \mathrm{Ab}$ & 7.11 & $7.83 \mathrm{Aa}$ & $3.95 \mathrm{Bb}$ & 5.89 \\
\hline NAA + ethephon & $5.87 \mathrm{Ab}$ & $6.75 \mathrm{Ab}$ & 6.31 & 7.74Aa & $5.77 \mathrm{Ba}$ & 6.75 \\
\hline 1-MCP & $5.97 \mathrm{Ab}$ & $4.58 \mathrm{Bd}$ & 5.27 & $0.51 \mathrm{Ad}$ & 1.19Ac & 0.85 \\
\hline $\mathrm{ABS}$ & $6.31 \mathrm{Ab}$ & $5.28 \mathrm{Ac}$ & 5.79 & $0.46 \mathrm{Ad}$ & $1.04 \mathrm{Ac}$ & 0.75 \\
\hline $\mathrm{AVG}+\mathrm{ABS}$ & $5.47 \mathrm{Ab}$ & $4.01 \mathrm{Bd}$ & 4.74 & $0.14 \mathrm{Ad}$ & $0.96 \mathrm{Ac}$ & 0.55 \\
\hline$\underline{\mathrm{AVG}}+\underline{1-\mathrm{MCP}}$ & $5.59 \mathrm{Ab}$ & $3.59 \mathrm{Bd}$ & 4.59 & $0.10 \mathrm{Ad}$ & $0.59 \mathrm{Ac}$ & 0.34 \\
\hline Mean & 6.22 & 5.70 & - & 2.73 & 2.21 & - \\
\hline
\end{tabular}

${ }^{(1)}$ Means followed by equal letters, lowercase in the columns and uppercase in the lines, do not differ by the Scott-Knott test, at $5 \%$ probability. ${ }^{(2)}$ Control, sprayed water; AVG, aminoethoxyvinylglycine sprayed 30 days before harvest $(\mathrm{BH}) ; \mathrm{AVG}+$ ethephon applied ten days $\mathrm{BH}$; AVG + naphthaleneacetic acid (NAA) sprayed seven days BH; sole NAA, sprayed seven days BH; NAA + ethephon sprayed seven and ten days BH, respectively; 1-MCP applied during postharvest; ABS, ethylene absorption sachets applied during storage. 
of cooling rooms (Table 2). This indicated that these growth regulators changed the natural fruit ripening process, which could result in early ethylene peak and, consequently, in a faster fruit ripening after harvest, once ethylene initiates a series of biochemical reactions that leads to fruit ripening and senescence. Moreover, it stimulated cellular metabolism changes which are responsible for regulating fruit softening (Hayama et al., 2006). Low IEC was found in fruit

Table 3. Internal carbon dioxide concentration $\left(\mathrm{ICO}_{2}\right)$, mealiness incidence, and internal space of 'Brookfield' apples after eight-month storage in controlled atmosphere $\left(1.0 \mathrm{kPa} \mathrm{O}_{2}+2.0 \mathrm{kPa} \mathrm{CO}\right.$ ) and after six days of shelf life, at $20^{\circ} \mathrm{C}^{(1)}$.

\begin{tabular}{|c|c|c|c|c|c|}
\hline \multirow[t]{2}{*}{ Treatment $^{(2)}$} & \multicolumn{2}{|c|}{$\mathrm{ICO}_{2}\left(\mathrm{~mL} 100 \mathrm{~mL}^{-1}\right)$} & \multirow[t]{2}{*}{ Mean } & \multirow{2}{*}{$\begin{array}{c}\text { Mealiness } \\
(\%)\end{array}$} & \multirow{2}{*}{$\begin{array}{c}\text { Internal } \\
\text { space } \\
\left(\mathrm{g} 100 \mathrm{~g}^{-1}\right)\end{array}$} \\
\hline & $\begin{array}{l}\text { Chamber } \\
\text { opening }\end{array}$ & $\begin{array}{c}\text { Six-day-shelf } \\
\text { life }\end{array}$ & & & \\
\hline Control & $8.32 \mathrm{Ab}$ & $1.28 \mathrm{Ba}$ & 4.75 & $26 \mathrm{a}$ & $15.05 \mathrm{c}$ \\
\hline AVG & 9.76Aa & $0.85 \mathrm{Ba}$ & 5.30 & $9 \mathrm{~d}$ & $18.77 \mathrm{~b}$ \\
\hline AVG+ethephon & $4.80 \mathrm{Ac}$ & $1.70 \mathrm{Ba}$ & 3.25 & $17 \mathrm{c}$ & $15.29 \mathrm{c}$ \\
\hline AVG+NAA & $4.48 \mathrm{Ac}$ & $1.65 \mathrm{Ba}$ & 3.06 & $0 \mathrm{e}$ & $18.55 b$ \\
\hline NAA & $5.60 \mathrm{Ac}$ & $0.45 \mathrm{Bb}$ & 3.02 & $31 \mathrm{a}$ & $14.22 \mathrm{c}$ \\
\hline NAA+ethephon & 4.96Ac & $0.88 \mathrm{Ba}$ & 2.92 & $23 \mathrm{~b}$ & $16.41 \mathrm{c}$ \\
\hline 1-MCP & 3.84Ad & $0.42 \mathrm{Bb}$ & 2.13 & $23 \mathrm{~b}$ & $19.59 \mathrm{~b}$ \\
\hline ABS & $3.20 \mathrm{Ad}$ & $0.36 \mathrm{Bb}$ & 1.78 & $19 \mathrm{c}$ & $17.95 b$ \\
\hline $\mathrm{AVG}+\mathrm{ABS}$ & 2.24Ae & $1.57 \mathrm{Aa}$ & 1.90 & $0 \mathrm{e}$ & $21.46 \mathrm{a}$ \\
\hline $\mathrm{AVG}+1-\mathrm{MCP}$ & 3.68Ad & $0.40 \mathrm{Bb}$ & 2.04 & $0 \mathrm{e}$ & $21.18 \mathrm{a}$ \\
\hline Mean & 5.09 & 0.96 & - & 14.74 & 17.85 \\
\hline CV (\%) & & 33.17 & - & 26.48 & 5.23 \\
\hline
\end{tabular}

(1)Means followed by equal letters, lowercase in the columns and uppercase in the lines, do not differ by the Scott-Knott test, at 5\% probability. ${ }^{(2)}$ Control, sprayed water; AVG, aminoethoxyvinylglycine sprayed 30 days before harvest $(\mathrm{BH}) ; \mathrm{AVG}+$ ethephon applied ten days $\mathrm{BH}$; AVG + naphthaleneacetic acid (NAA) sprayed seven days BH; sole NAA, sprayed seven days BH; NAA + ethephon sprayed seven and ten days BH, respectively; 1-MCP applied during postharvest; $\mathrm{ABS}$, ethylene absorption sachets applied during storage. subjected to 1-MCP, ABS, AVG + ABS, and AVG $+1-\mathrm{MCP}$, at the opened cooling rooms and after six days of shelf life. It is worth noting that the IEC either decreased from the opening of cooling rooms or kept a similar concentration, but it never increased during shelf life. When IEC reduces after a shelf life period, an early climacteric peak may be the responsible for this, since it has been proven that ethephon application advances the ethylene peak. Steffens et al. (2006) also found higher ethylene production in fruit subjected to the preharvest ethephon sprays than in fruit without it.

$\mathrm{ICO}_{2}$ was reduced during shelf life, except for fruit that received the preharvest $\mathrm{AVG}+\mathrm{ABS}$ treatment (Table 3). These higher $\mathrm{ICO}_{2}$ values at the opening of cooling rooms result from the high $\mathrm{CO}_{2}$ concentration $(2.0 \mathrm{kPa})$ in the chamber, during storage, since $\mathrm{CO}_{2}$ diffusion is more difficult from inside to the outside of fruit, when there was a high-carbon dioxide level in the storage room. At the opening of cooling rooms, fruit which have hardly received the AVG + ABS treatment had the lowest $\mathrm{ICO}_{2}$ concentration. This result may be related to the high gas diffusion in fruit of these treatments (Table 1).

Mealiness, one of the most important physiological disorder in apples, is related to ethylene concentration (Prasanna et al., 2007; Payasi et al., 2009), but it also occurs as a consequence of anaerobic metabolism, which culminates in ethanol accumulation (Franck et al., 2007). In the present study, the control and NAA treatments showed the highest mealiness occurrence (Table 3). Surprisingly, however, when NAA was sprayed after AVG, fruit did not show any symptoms of this physiological disorder. This is possibly due to the lower ethylene production, when fruit were subjected to AVG + NAA, in relation to fruit subjected to sole NAA application (Table 2), once ethylene is the "trigger"

Table 4. Correlation matrix of evaluated variables on 'Brookfield' apples after eight-month storage in controlled atmosphere $\left(1.0 \mathrm{kPa} \mathrm{O}_{2}+2.0 \mathrm{kPa} \mathrm{CO}_{2}\right)$ plus six days of shelf life at $20^{\circ} \mathrm{C}$.

\begin{tabular}{|c|c|c|c|c|c|c|c|}
\hline Variable & Gas diffusion & IEC & $\mathrm{ICO}_{2}$ & Ethylene production & Respiration rate & Mealiness & Internal space \\
\hline Gas diffusion & - & & & & & & \\
\hline IEC & -0.40 & - & & & & & \\
\hline $\mathrm{ICO}_{2}$ & ns & ns & - & & & & \\
\hline Ethylene production & -0.77 & 0.94 & ns & - & & & \\
\hline Respiration rate & -0.82 & 0.82 & ns & 0.88 & - & & \\
\hline Mealiness & -0.57 & ns & ns & ns & 0.66 & - & \\
\hline Internal space & 0.92 & ns & ns & -0.75 & -0.89 & -0.75 & - \\
\hline
\end{tabular}

${ }^{n}$ Nonsignificant Pearson correlation between variables, at $5 \%$ probability. 
from the polygalacturonase and pectinmethylesterase activities that transform protopectin molecules into soluble pectin and increase mealiness-pulp incidence (Prasanna et al., 2007; Payasi et al., 2009). Nevertheless, fruit subjected to AVG + ABS and AVG + 1-MCP did not show any symptom of mealiness. This was probablly related to the low ethylene production and to the higher internal space in fruit of these treatments, according to the negative correlation observed between these two variables (Table 4). The higher internal space allowed for better gas exchanges and maintained better quality in fruit after storage, by enhancing membrane integrity.

Gas diffusion and physiological disorder are closely related. However, mealiness and gas diffusion may also be related to fruit internal space, considering the significant Pearson correlation (Table 4). Fruit had higher internal space when subjected to AVG + $\mathrm{ABS}$ and $\mathrm{AVG}+1-\mathrm{MCP}$ (Table 3). It is likely that this high internal space led to higher gas diffusion and, also, inhibited mealiness incidence in fruit from these treatments. Researchers have mentioned that cell integrity loss lead to an obstruction of pores, which allowed gas exchange and changes in the internal atmosphere. Therefore, cell integrity loss may result in ethanol accumulation and in physiological disorders (Franck et al., 2007). However, there are evidences that the physiological disorders, in this case, is caused by low-energy production from the anaerobic metabolism, resulting in a low-defense mechanism (Pedreschi et al., 2009). Lower incidence of physiological disorders in these treatments also promoted higher cell wall integrity.

\section{Conclusions}

1. Growth regulators change gaseous diffusion through the pulp of 'Brookfield' apples, and the AVG + ABS treatment delays ripening by controlling ethylene synthesis and keeping higher gas diffusion rates.

2. NAA spraying in the field, with or without another growth regulator, increases ripening rate and reduces gas diffusion during shelf life.

3. AVG spraying cannot avoid the ethephon effect on the ripening process, which reduces internal space and allows for mealiness incidence.

4. Gas diffusion and internal space have an inverse correlation with IEC, ethylene production, respiration rate, and mealiness incidence.
5. Mealiness in 'Brookfield' apples can be controlled by spraying $\mathrm{AVG}+\mathrm{NAA}, \mathrm{AVG}+\mathrm{ABS}$, and $\mathrm{AVG}+$ 1-MCP.

\section{References}

ARGENTA, L.; FAN, X.T.; MATTHEIS, J. Impact of watercore on gas permeance and incidence of internal disorders in 'Fuji' apples. Postharvest Biology and Technology, v.24, p.113-122, 2002. DOI: 10.1016/S0925-5214(01)00137-5.

BAN, T.; KUGISHIMA, M.; OGATA, T.; SHIOZAKI, S.; HORIUCHI, S.; UEDA, H. Effect of ethephon (2-chloroethylphosphonic acid) on the fruit ripening characters of rabbiteye blueberry. Scientia Horticulturae, v.112, p.278-281, 2007. DOI: 10.1016/j.scienta.2006.12.027.

BRACKMANN, A.; ANESE, R. de O.; PINTO, J.A.V.; BOTH, V.; VENTURI, T.L.; SCHORR, M.R.W. Aplicação de 1-metilciclopropeno e absorção de etileno em maçã da cultivar 'Royal Gala' colhida tardiamente. Ciência Rural, v.40, p.2074-2080, 2010. DOI: 10.1590/S0103-84782010005000157.

BRACKMANN, A.; PINTO, J.A.V.; WEBER, A.; NEUWALD, D.A.; STEFFENS, C.A. Indução da perda de massa fresca e a ocorrência de distúrbios fisiológicos em maçãs 'Royal Gala' durante o armazenamento em atmosfera controlada. Revista Brasileira de Armazenamento, v.32, p.87-92, 2007.

CORRÊA, T.R.; STEFFENS, C.A.; TANAKA, H.; AMARANTE, C.V.T. do; BRACKMANN, A.; ANESE, R. de O. Manejo do etileno em ameixas 'Laetitia' armazenadas sob atmosferas controlada e modificada ativa. Revista Brasileira de Fruticultura, v.33, p.723-729, 2011. DOI: 10.1590/S0100-29452011005000094.

FAWBUSH, F.; NOCK, J.F.; WATKINS, C.B. Antioxidant contents and activity of 1-methylcyclopropene (1-MCP)-treated 'Empire' apples in air and controlled atmosphere storage. Postharvest Biology and Technology, v.52, p.30-37, 2009. DOI: 10.1016/j. postharvbio.2008.08.014.

FAWBUSH, F.; NOCK, J.F.; WATKINS, C.B. External carbon dioxide injury and 1-methylcyclopropene (1-MCP) in the 'Empire' apple. Postharvest Biology and Technology, v.48, p.92-98, 2008. DOI: 10.1016/j.postharvbio.2007.09.005.

FRANCK, C.; LAMMERTYN, J.; HO, Q.T.; VERBOVEN, P.; VERLINDEN, B.; NICOLAÏ, B.M. Browning disorders in pear fruit. Postharvest Biology and Technology, v.43, p.1-13, 2007. DOI: $10.1016 /$ j.postharvbio.2006.08.008.

HAYAMA, H.; SHIMADA, T.; FUJII, H.; ITO, A.; KASHIMURA, Y. Ethylene-regulation of fruit softening and softening-related genes in peach. Journal of Experimental Botany, v.57, p.4071-4077, 2006. DOI: $10.1093 / \mathrm{jxb} / \mathrm{erl} 178$.

HO, Q.T.; VERLINDEN, B.E.; VERBOVEN, P.; VANDEWALLE, S.; NICOLAÏ, B.M. A permeation-diffusion-reaction model of gas transport in cellular tissue of plant materials. Journal of Experimental Botany, v.57, p.4215-4224, 2006. DOI: 10.1093/ jxb/erl198.

LI, J.; YUAN, R. NAA and ethylene regulate expression of genes related to ethylene biosynthesis, perception, and cell wall 
degradation during fruit abscission and ripening in 'Delicious' apples. Journal of Plant Growth Regulators, v.27, p.283-295, 2008. DOI: $10.1007 / \mathrm{s} 00344-008-9055-6$.

PAYASI, A.; MISHRA, N.N.; CHAVES, A.L.S.; SINGH, R. Biochemistry of fruit softening: an overview. Physiology and Molecular Biology of Plants, v.15, p.103-113, 2009. DOI: 10.1007/s12298-009-0012-z.

PEDRESCHI, R.; FRANCK, C.; LAMMERTYN, J.; ERBAN, A.; KOPKA, J.; HERTOG, M.; VERLINDEN, B.; NICOLAÏ, B. Metabolic profiling of 'Conference' pears under low oxygen stress. Postharvest Biology and Technology, v.51, p.123-130, 2009. DOI: 10.1016/j.postharvbio.2008.05.019.

PINTO, J.A.V.; BRACKMANN, A.; SCHORR, M.R.W.; VENTURINI, T.L.; THEWES, F.R. Indução de perda de massa na qualidade pós-colheita de pêssegos 'Eragil' em armazenamento refrigerado. Ciência Rural, v.42, p.962-968, 2012. DOI: 10.1590/ S0103-84782012000600002.

PRASANNA, V.; PRABHA, T.N.; THARANATHAN, R.N. Fruit ripening phenomena: an overview. Critical Reviews in Food Science and Nutrition, v.47, p.1-19, 2007. DOI: 10.1080/10408390600976841.

SALAS, N.A.;MOLINA-CORRAL,F.J.;GONZÁLES-AGUILAR, G.A.; OTERO, A.; SEPULVEDA, D.R.; OLIVAS, G.I. Volatile production by 'Golden Delicious' apples is affected by preharvest application of aminoethoxyvinylglycine. Scientia Horticulturae, v.130, p.436-444, 2011. DOI: 10.1016/j.scienta.2011.07.017.

SCHOTSMANS, W.; VERLINDEN, B.E.; LAMMERTYN, J.; NICOLAÏ, B.M. Simultaneous measurement of oxygen and carbon dioxide diffusivity in pear fruit tissue. Postharvest
Biology and Technology, v.29, p.155-166, 2003. DOI: 10.1016/ S0925-5214(02)00251-X.

SCHOTSMANS, W.; VERLINDEN, B.E.; LAMMERTYN, J.; NICOLAII, B.M. The relationship between gas transport properties and the histology of apple. Journal of the Science of Food and Agriculture, v.84, p.1131-1140, 2004. DOI: 10.1002/jsfa.1768.

SEN, C.; MISHRA, H.N.; SRIVASTAV, P.P. Modified atmosphere packaging and active packaging of banana (Musa spp.): a review on control of ripening and extension of shelf life. Journal of Stored Products and Postharvest Research, v.3, p.122-132, 2012. DOI: 10.5897/JSPPR11.057.

STEFFENS, C.A.; BRACKMANN, A.; PINTO, J.A.V.; EISERMANN, A.C. Taxa respiratória de frutas de clima temperado. Pesquisa Agropecuária Brasileira, v.42, p.313-321, 2007. DOI: 10.1590/S0100-204X2007000300003.

STEFFENS, C.A.; GUARIENTI, A.J.W.; STORCK, L.; BRACKMANN, A. Maturação da maçã 'Gala' com a aplicação pré-colheita de aminoetoxivinilglicina e ethephon. Ciência Rural, v.36, p.434-440, 2006. DOI: 10.1590/S0103-84782006000200012.

WANG, Z.Y.; DILLEY, D.R. Aminoethoxyvinylglycine, combined with ethephon, can enhance red color development without over-ripening apples. Hortscience, v.36, p.328-331, 2001.

WATKINS, C.B. The use of 1-methylcyclopropene (1-MCP) on fruits and vegetables. Biotechnology Advances, v.24, p.389-409, 2006. DOI: 10.1016/j.biotechadv.2006.01.005.

YILDIZ, K.; OZTURK, B.; OSKAN, Y. Effects of aminoethoxyvinylglycine (AVG) on preharvest fruit drop, fruit maturity, and quality of 'Red Chief' apple. Scientia Horticulturae, v.144, p.121-124, 2012. DOI: 10.1016/j.scienta.2012.07.005.

Received on November 7, 2013 and accepted on April 28, 2014 